\title{
Ingestive Behavior of Cows in Pastures Andropogon gayanus and Brachiaria decumbens in Southern State of Piauí, Brazil
}

\author{
Wéverton José Lima Fonseca ${ }^{1}$, Wéverson Lima Fonseca ${ }^{2}$, Paulo Henrique Amaral Araújo de Sousa ${ }^{3}$, Leandro de \\ Oliveira Guerra ${ }^{4}$, Carlos Syllas Monteiro Luz ${ }^{5}$, Tatiano Ribeiro dos Santos ${ }^{6}$, Gleissa Mayone Silva Vogado, \\ Laylson da Silva Borges ${ }^{7}$, Teobaldo Florêncio de Almeida Júnior ${ }^{4} \&$ Severino Cavalcante de Sousa Júnior ${ }^{8}$ \\ ${ }^{1}$ PIBIC/CNPq - Undergraduate Course of Bachelor of Animal Science - UFPI/CPCE, Brazil \\ ${ }^{2}$ PIBIC/CNPq - Undergraduate Course Bachelor in Agricultural Engineering - UFPI/CPCE, Brazil \\ ${ }^{3} \mathrm{ICV}$ - Undergraduate Course of Bachelor of Animal Science - UFPI/CPCE, Brazil \\ ${ }^{4}$ Course of Bachelor of Animal Science - UFPI/CPCE, Brazil \\ ${ }^{5}$ Department of Animal Science - UFPI/CPCE, Brazil \\ ${ }^{6}$ Agricultural Engineering - UFPI/CPCE, Brazil \\ ${ }^{7}$ PIBIT/CNPq - Undergraduate Course of Bachelor of Animal Science - UFPI/CPCE, Brazil \\ ${ }^{8} \mathrm{DZO} / \mathrm{UFPI} / \mathrm{CPCE}$, Brazil \\ Correspondence: Wéverton José Lima Fonseca, Undergraduate Course of Bachelor of Animal Science, Federal \\ University of Piauí, Bom Jesus, PI64900-000, Brazil. Tel: 55-89-9939-3260. E-mail: wevertonsbz@yahoo.com
}

\author{
Received: November 15, 2013 Accepted: January 9, 2014 Online Published: March 15, 2014 \\ doi:10.5539/jas.v6n4p144 \\ URL: http://dx.doi.org/10.5539/jas.v6n4p144
}

\begin{abstract}
The research was conducted at the experimental farm of the Agricultural College of Bom Jesus, which is located at $135 \mathrm{~km} 3 \mathrm{BR}$, in the region of the valley Gurguéia southern state of Piauí. We used 10 crossbred cows of Holstein $\mathrm{x}$ Gir. The experimental design was completely randomized with two treatments (the pastures of grasses Andropogon gayanus and Brachiaria decumbens), with five replicates (five animals per treatment). The trial lasted five days. Two evaluations were made with duration of 24 hours each, conducted during a day, and the average of the two ratings was used in the statistical analyzes. The evaluations were performed on 20 to 24 July 2013. The cows grazed more time in the morning around 7-10 hours and late afternoon extending into the night with peak until 19:00 hours. The idle time was greater at the end of the night that matches the period of reduced grazing activity. The cows grazed more time during the day in the pasture of Brachiaria decumbens ( 8.53 hours) compared to pasture Andropogon gayanus ( 8.03 hours). With respect to time grazing night, the situation was reversed, the animals grazed longer during the day and slowed down during the night (3.16 hours grazing) in the pasture of Brachiaria decumbens. The animals had a higher number of bits (14128.92) in grazing Brachiaria decumbens compared to Andropogon gayanus (10134.00).
\end{abstract}

Keywords: bits, animal behavior, loitering, grazing

\section{Introduction}

The feeding behavior of beef cattle or milk is influenced by the structure of the pasture and the heterogeneity of the spatial distribution of vegetation, characterized by a number of factors that can affect grazing behavior. According to (Maggioni et al., 2009), the nutritional value of available forage usually has great influence on the amount of forage consumed by ruminants.

A good performance in animals producing milk is a reflection mainly in its nutrient management and environmental effects that are submitted. Thus to improve the index created productive animals on pasture is good to know the pasture - animal interactions - environment.

Knowledge of animal behavior is essential for obtaining optimal conditions for rearing and feeding Swenson (1996). According (Pires et al., 2001), specifically bovine animals are capable of responding to different types of structures and variables pasture behavioral altering their levels in an attempt to survive. Thus, the basic concepts of power, combined with the knowledge of feeding behavior, should be used to increase productivity. 
The feeding behavior or the act of swallowing animals is influenced by the stage of maturity of grass, palatability, feeding behavior of cattle matrices and structure of grassland being the main factor that affects the behavioral variables of consumption of animals. The potential of grassland is characterized by the quantity and quality of forage that is capable of producing. According to Forbes (1995), which further affects the consumption of forage is the height of available forage, which is closely related to the mass of available forage.

Thus, a basic objective of the whole system for cattle grazing is to meet the nutritional needs of animals throughout the year, keeping the permanent provision of food in sufficient quantity and quality, in order to get a satisfactory answer for productive part of the animals (Pardo et al., 2003).

This study aimed to compare the behavior of cows in pastures Andropogon gayanus and Brachiaria decumbens for possible differences in the time spent on grazing, rest, at the rate and total bites of animals.

\section{Materials and Methods}

The experiment was conducted at the experimental farm of the Agricultural College of Bom Jesus, belonging to the Federal University of Piauí which is located at $135 \mathrm{~km} 3$ BR, in the valley Gurguéia southern state of Piauí. The region has a tropical climate conditions of the semiarid region that corresponds to the dry climate and high temperatures. Conducted during the summer dragging for fall, which is the period of the rainy season, common to all regions of northeastern Brazil. Formed pastures planaltina (Andropogon gayanus) and braquiarinha (Brachiaria decumbens) were used in a flat area of 1 ha for each type of pasture. We used 10 crossbred cows of Holstein x Gir.

The trial lasted five days and the animals were already adapted to pasture. Two evaluations were made with duration of 24 hours each, conducted during a day, and the average of the evaluations was used in the statistical analyzes. The evaluations were performed on 20 and 24 July 2013. The experimental design was completely randomized with two treatments (the pastures of grasses Andropogon gayanus and Brachiaria decumbens), with five replicates (five animals per treatment), each picket comprised an area of 1 ha. The variables analyzed were total daily grazing time, grazing time, morning, afternoon grazing time, grazing time night, the total time of leisure, leisure time morning, afternoon leisure time, leisure time night, number of seizure per minute in the morning, afternoon, evening and the number of seizure diaries.

The grazing time and idleness were obtained by visual observations of the animals every 10 minutes and the total time the sum total of the times in which the animals were observed in a given state, based on the methodology described by (Costa et al., 2003).

Was regarded as one of the morning 07 to $12 \mathrm{~h}$, the period from 12:00 hours to 19:00 and the period of the night included the interval between 19 and $07 \mathrm{~h}$, the daily period comprised 24 hours of each day of observation. Grazing time understood the activities of search and seizure of material, while the leisure time referred to all the extras ruminating and grazing activities.

The seizure rate was obtained by counting the number of direct apprehension observed within one minute and the resulting average of observations every ten minutes, when the animals were grazing. The number of daily seizure was calculated by the product of the average rate of seizure and daily grazing time in minutes. The data relating to grazing times, the leisure and the rate and number of observed seizure diaries were submitted to analysis of variance and means were compared by Tukey test at $5 \%$ significance level, using the statistical program SISVAR, version 5.3.

\section{Results and Discussion}

In Figure 1, can be observed daily variations in the behavior of crossbred Holstein x Gir in pastures Andropogon gayanus and Brachiaria decumbens. 


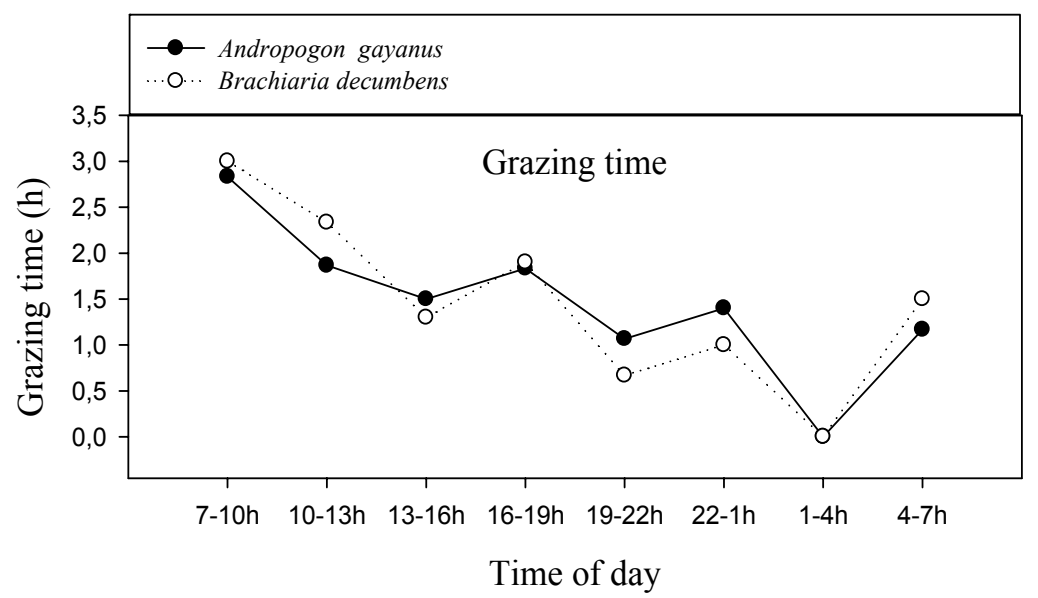

Figure 1. Changes in grazing behavior of cows in pasture Andropogon gayanus and Brachiaria decumbens

It can be seen that, as the feeding time, there were peaks in the early morning hours (around 7-10 hours) and late afternoon extending into the night (peak at 19:00 hours), which corresponds to the time that the animals were in grazing activity. Second (Vieira et al., 2007), similar behavior observed with heifers Girolando, where it was found more time grazing in the early morning and late afternoon, with peaks of grazing between $16 \mathrm{~h}$ and $17 \mathrm{~h}$ hours.

The animals grazed during the day, to a lesser extent in the period from 13 to 16 hours, extending to 1 am next in the pasture of Brachiaria decumbens. From that time, there was a reduction in grazing 4hours till dawn. For animals that were grazing Andropogon gayanus, we can observe that there was a reduction of grazing from 1hour, 4hours back to grazing the next morning, just like in the pasture of Brachiaria decumbens.

In Figure 2, can be observed daily changes in leisure behavior of crossbred cows Holstein x Gir in pastures of Brachiaria decumbens and Andropogon gayanus.

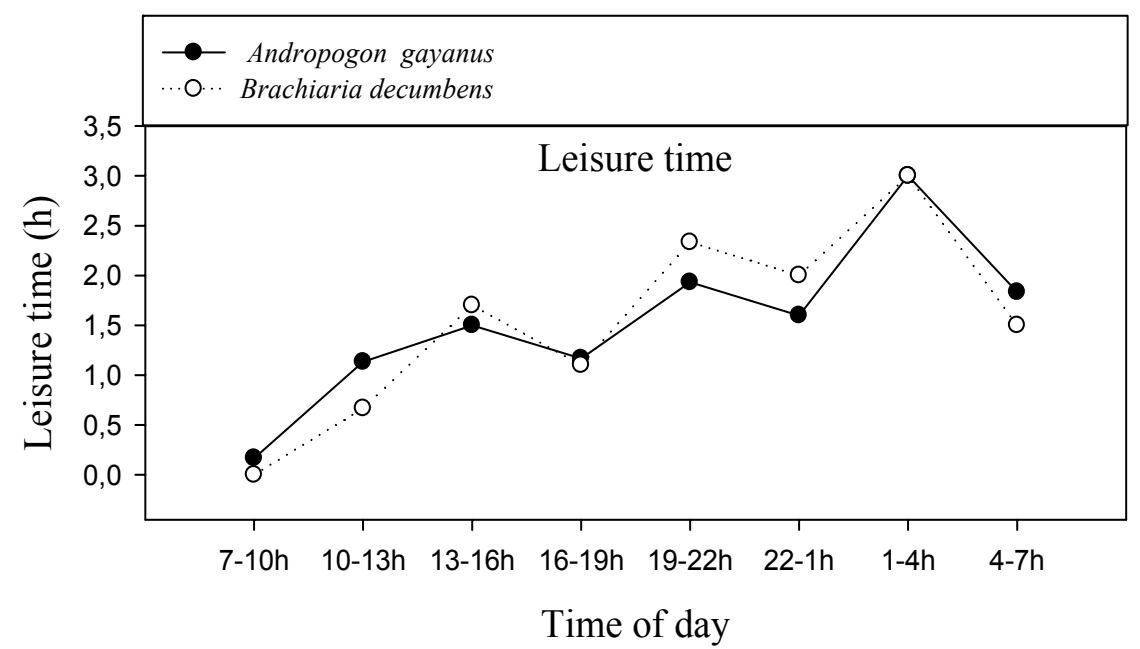

Figure 2. Changes in leisure behavior of cows in the pasture Andropogon gayanus and Brachiaria decumbens

We can observe that in both the two pastures Andropogon gayanus and Brachiaria decumbens, idle time was higher at the end of the night that matches the time when the animals are not exercising any ingestive behavior. According to Waring (1975), it was found that the animals related to half the day and the end of the night as the times of day with lower grazing activity.

In Figure 3, can be observed daily variations in the behavior of pieces of crossbred Holstein x Gir in pastures Andropogon gayanus and Brachiaria decumbens. 


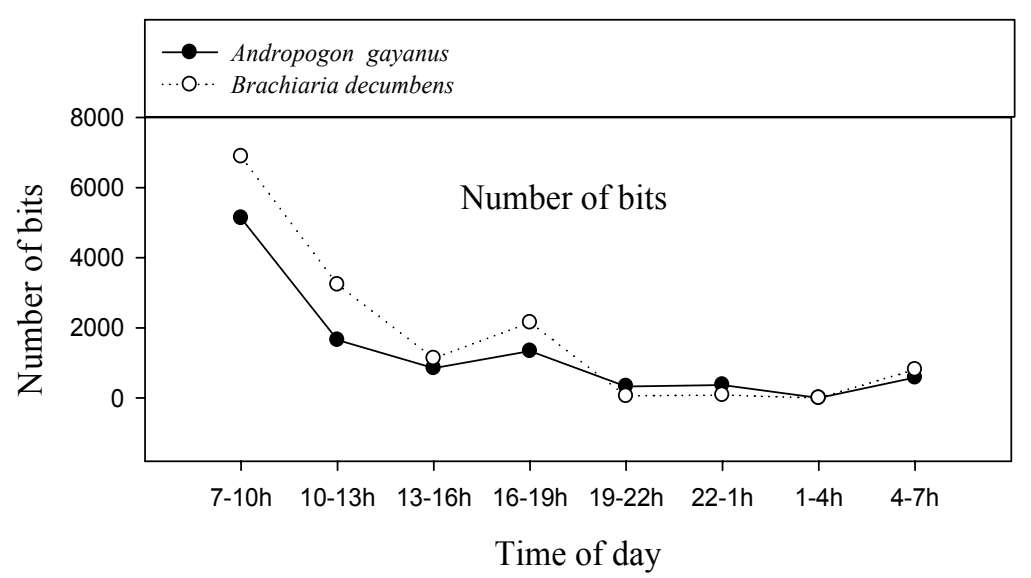

Figure 3. Variation in the behavior of bits of cows in the pasture Andropogon gayanus and Brachiaria decumbens

We can observe in Figure 3 that animals ingest more material in the morning and consequently the number of bits was the most intense peaks (7-10 hours). Therefore we evaluated the grasses Brachiaria decumbens realize that had the largest number of bits compared to Andropogon gayanus pasture in the morning hours, it actually had a more selective behavior of animals and acceptability of forage mass ingested. Already in the late afternoon and extending to the hours of the night (16-19 hours) the bit number had gradually increased.

According to Van Rees \& Hutson (1983), intensive grazing occurred in the first four hours of the day, but also observed the same in the late afternoon, afternoons while the animals grazed intermittently. The number of bites during the day was less intense peak of (13-16 hours), extending to 1am following in both pasture evaluated. From that time, we realize that hears a reduction in the number of bits until $4 \mathrm{am}$. It is evident that the animals in the pasture Brachiaria started deccumbens having a gradually increasing the number of bits following the 4 o'clock apart.

Results as described in Table 1, lists the times of heifers grazing pastures on both Andropogon and Brachiaria decumbens gayanus. There was a significant difference $(\mathrm{P}<0.05)$, which observed that cows spent more time grazing during the day, but no significant difference $(\mathrm{P}>0.05)$ in both types of pasture, this can be explained due to remain part of the night lying ruminating and also because the animals do not show preference for one of the fodder that were used in this experiment. Vieira et al. (2007) observed similar behavior in a study conducted with heifers Girolando, where it was found more time grazing in the early morning and late afternoon, with peaks of grazing between 16 and 17 hours.

Table 1. Grazing time of cows during daytime, night and day

\begin{tabular}{lcll}
\hline \multirow{2}{*}{ Pasture } & \multicolumn{3}{l}{ Grazing time (hours) } \\
\cline { 2 - 4 } & Daytime & Nightly & Daily \\
\hline Andropogon gayanus & $8,03^{\mathrm{aA}}$ & $3,63^{\mathrm{aB}}$ & $11,66^{\mathrm{a}}$ \\
Brachiaria decumbens & $8,53^{\mathrm{aA}}$ & $3,16^{\mathrm{aB}}$ & $11,70^{\mathrm{a}}$ \\
\hline $\mathrm{CV}(\%)$ & 17,65 & & 12,25 \\
\hline
\end{tabular}

Means followed by the same lowercase and uppercase in the column on the line do not differ $(\mathrm{P}<0.05)$ by Tukey test at $5 \%$ level of probability.

With regard to night grazing, it was observed that there was no difference $(\mathrm{P}>0.05)$ on types of grass used for feeding the cattle dies, possibly because of it being irrigated pastures and thereby make available green mass quality for foraging of animals. It was established that the evening had the lowest grazing time analyzed in the present study, which can be justified is that the animals at night are big part of the time lying ruminating as it is described in the nocturnal period in Table 2. Waring (1975), with a job in similar conditions, found that animals related to half of the day and the end of the night as the time of day lower grazing activity. In total daily grazing time, there was no statistical difference by Tukey test at 5\% significance regarding the pastures studied, showing 
that the animals under the conditions of this experiment have not changed the grazing habits of the measure that was modified type of grass, where there was a daily grazing time around 11 hours.

In Table 2 we observe that in general, the animals had a longer time in idleness during the night with a magnitude of 8.83 hours of leisure time compared to daytime, showing that cows had an increase of $255 \%$ in time spent in idleness when they were in the pasture of Brachiaria decumbens. We observed no significant difference for the two pastures Andropogon and Brachiaria decumbens gayanus by Tukey test $(\mathrm{P}>0.05)$, which is justified by higher peak number of bits and grazing occurred during the day, agreeing with grazing time which was lower during the night (Table 1), the cows spent more time lying down at night. According to Camargo (1988), the animals prefer to remain standing idle during the hottest hours of the day, while at night, keep lying.

Table 2. Leisure time for cows during daytime, night and day

\begin{tabular}{lccc}
\hline \multirow{2}{*}{ Pasture } & \multicolumn{3}{c}{ Leisure time (hours) } \\
\cline { 2 - 4 } & Daytime & Nightly & Daily \\
\hline Andropogon gayanus & $3,96^{\mathrm{aB}}$ & $8,36^{\mathrm{aA}}$ & $12,33^{\mathrm{a}}$ \\
Brachiaria decumbens & $3,46^{\mathrm{aB}}$ & $8,83^{\mathrm{aA}}$ & $12,30^{\mathrm{a}}$ \\
\hline $\mathrm{CV}(\%)$ & 16,75 & & 11,62
\end{tabular}

Means followed by the same lowercase and uppercase in the column on the line do not differ $(\mathrm{P}<0.05)$ by Tukey test at $5 \%$ level of probability.

It was evident that the comparison of time in idle shifts hears rated daytime and nighttime differences significant at $(\mathrm{P}<0.05)$ in pastures Andropogon gayanus and Brachiaria decumbens. Already at the time in idleness daily noted mind showed a higher value in the pasture Andropogon gayanus and not hear a significant difference by Tukey test $(\mathrm{P}<0.05)$ in both pastures evaluated. Idleness can be defined as the period in which the animal is not eating, chewing or ingesting water, and has an average duration of ten hours daily Albright (1993).

In Table 3 it can be seen that the bite rate was lower for animals on pasture Andropogon gayanus, 9158.72 bits daytime, while for Brachiaria decumbens value was 13552.62 bits daytime.

Table 3. Mean values for the number of bits day, night and dairy cows in pastures Andropogon gayanus and Brachiaria decumbens

\begin{tabular}{lccc}
\hline \multirow{2}{*}{ Pasture } & \multicolumn{3}{c}{ Number of bits / minute } \\
\cline { 2 - 4 } & Daytime & Nightly & Daily \\
\hline Andropogon gayanus & $9158,72^{\mathrm{bA}}$ & $975,28^{\mathrm{aB}}$ & $10134,00^{\mathrm{a}}$ \\
Brachiaria decumbens & $13552,62^{\mathrm{aA}}$ & $576,30^{\mathrm{aB}}$ & $14128,92^{\mathrm{a}}$ \\
\hline CV $(\%)$ & 12,53 & & 24,23 \\
\hline
\end{tabular}

Means followed by the same lowercase and uppercase in the column on the line do not differ $(\mathrm{P}<0.05)$ by Tukey test at $5 \%$ level of probability.

Table 3 shows the significant difference was observed for daytime with the highest bite rate for animals in the pasture of Brachiaria decumbens (13552.62) bits daytime, while for Andropogon gayanus, the value was (9158.72) bits day. This inferiority is due probably to the bovine opt for smaller pasture that was the Brachiaria decumbens. According Sbrissia and Da Silva (2001), the leaf: stem ratio has varied relevance according to the forage species, being lower in species of tender stem and lower lignification.

Regarding the total number of bits of the cows in the pastures of Brachiaria decumbens and Andropogon gayanus, the animals showed a number of pieces daily in the pasture of Brachiaria decumbens (14128.92), while in the pasture of Andropogon gayanus, this number was lower a $(10,134.00)$ bits $(\mathrm{P}<0.05)$.

In Table 4 we can observe in general a significant difference for the two pastures Andropogon gayanus and Brachiaria decumbens $(\mathrm{P}<0.05)$. The rate of the number of bites per minute was lower for animals on pasture Andropogon gayanus (24.83) bits minute in the morning shift, while for the Brachiaria decumbens, the value was 
(32.96) bits minute. Mendes et al. (2009) the increase in bit rate is a mechanism to maintain the rate of forage intake when changes occur in the pasture that provide lower bite mass. This variable is of the greatest importance in feeding behavior and explains the largest percentage of the variance in daily forage intake, since the bit rate and grazing time have secondary role Chacon and Stobbs (1976).

This inferiority was due, according to the opt more for cattle pasture with an average height of 30 centimeters, thus the pasture of Brachiaria decumbens showed up better for this characteristic. Lowers forage availability and especially the smallest blade: stem ratio may explain the more selective behavior of animals. According to Van Soest (1994), the increased consumption of sheets relative to the stem is assigned to more rapidly digested and the shorter retention time in the rumen, as well as greater accessibility and ease of apprehension.

Table 4. Mean values for the number of bites per minute morning, afternoon, evening and daily bits of cows in the pastures of Brachiaria decumbens and Andropogon gayanus

\begin{tabular}{lcccc}
\hline \multirow{2}{*}{ Pasture } & \multicolumn{3}{c}{ Number of bits / minute } \\
\cline { 2 - 4 } & In Morning & In Afternoon & Nightly & Daily \\
\hline Andropogon gayanus & $24,83^{\mathrm{bA}}$ & $10,80^{\mathrm{aB}}$ & $4,43^{\mathrm{aB}}$ & $13,35^{\mathrm{a}}$ \\
Brachiaria decumbens & $32,96^{\mathrm{aA}}$ & $17,06^{\mathrm{aB}}$ & $2,97^{\mathrm{aC}}$ & $17,66^{\mathrm{a}}$ \\
\hline $\mathrm{CV}(\%)$ & & 31,99 & & 25,01
\end{tabular}

Means followed by the same lowercase and uppercase in the column on the line do not differ (P<0.05) by Tukey test at $5 \%$ level of probability.

This result was higher than in the present experiment for animals in the pasture of Brachiaria decumbens, which was 24.83 bits per minute and returned to the lower animals in the pasture of Andropogon gayanus, 32.96 bits per minute. There was a significant difference $(\mathrm{P}<0.05)$ related to shifts in the afternoon and evening for the Brachiaria decumbens pasture with higher number of bites per minute in the afternoon (17.06) and presenting a lower value on the night shift (2.97) number of bites per minute. It is noteworthy that the frequency of bites varies greatly with environmental conditions, and the structural quality of the pasture. According Paulino (2001), the attitude of grazing cattle to select a diet with the highest quality is a manifestation of the strategy to improve the nutritional balance.

Time total daily number of bites per minute, there was no statistical difference by Tukey test between the two pastures (Andropogon gayanus and Brachiaria decumbens), the animals showed a number of bits daily total (17.66) in the pasture of Brachiaria decumbens, while in the pasture of Andropogon gayanus, this number was less than 13.35 bits $(\mathrm{P}>0.05)$.

\section{Conclusion}

The study of the behavior of grazing on grasses with different structures is suggested that grazing management strategies should take into account differences in grazing behavior. It was found that the cows had longer grazing in the morning regarding the daytime shift with a greater number of bits in the pasture Brachiaria decumbens.

\section{Acknowledgment}

I want to thank, first of all to God for strength and courage throughout this long journey. I also thank all the teachers who have accompanied me during graduation especially my tutor Dr. Severino Cavalcante de Sousa Junior.

\section{References}

Albrigh, J. L. (1993). Nutrition, feeding and calves: feeding behaviour of dairy cattle. Journal of Dairy Science, 76(2), 485-498. http://dx.doi.org/10.3168/jds.S0022-0302(93)77369-5

Camargo, A. C. (1988). Comportamento de vacas da raça Holandesa em confinamento do tipo "free stall”, no Brasil Central. 146f. Dissertação (Mestrado em Zootecnia) - Curso de Pós-graduação em Zootecnia, Fundação de Estudos Agrários Luiz de Queiroz.

Chacon, E., \& Stobbs, T. H. (1976). Influence of progressive defoliationof a grass sward on the eating behavior of cattle. Australian Journal of Agriculture Research, 7(3), 709-727. http://dx.doi.org/10.1071/AR9760709 
Costa, C. O., Fischer, V., \& Vetromilla, M. A. M. (2003). Comportamento ingestivo de vacas Jersey confinadas durante a fase inicial da lactação. Revista Brasileira de Zootecnia, 32(2), 418-424. http://dx.doi.org/10.1590/S1516-35982003000200021

Forbes, J. M. (1995). Voluntary food intake and diet selection in farm animals (p. 532). Wallinford: CAB International.

Maggioni, D., Marques, J. A., Rotta, P. P., Zawadzki, F., Ito, R. H., \& Prado, I. N. (2009). Ingestão de alimentos. Ciências Agrárias, Londrina, 30(4), 963-974. http://dx.doi.org/10.5433/1679-0359.2009v30n4p963

Mendes, A. M. (2009). Influência da suplementação sobre o comportamento ingestivo de vacas leiteiras mestiças em pastagens de Bachiaria decumbens Stapf. Dissertação apresentada ao Programa de Pós-Graduação em Zootecnia da Universidade Federal Rural de Pernambuco, como parte dos requisitos para obtenção do grau de Mestre.

Pardo, R. M. P., Fischer, V., Balbinotti, M., Moreno, C. B., Ferreira, E. X., Vinhas, R. I., \& Monks, P. L. (2003). Comportamento ingestivo diurno de novilhos em pastejo submetidos a níveis crescentes de suplementação $\begin{array}{lllll}\text { energética. Revista Brasileira de } & \text { Zootecnia, 32(6), }\end{array}$ http://dx.doi.org/10.1590/S1516-35982003000600016

Paulino, M. F., Detmann, E., \& Zervoudakis. J. T. (2001). Suplementos múltiplos para recria e engorda de bovinos em pastejo. In: Simpósio de produção de gado de corte, 2. 2001, Viçosa. Anais... Universidade Federal de Viçosa. Viçosa (p. 187-232).

Pires, M. F. A., Vilela, D., \& Alvim, M. J. (2001). Comportamento alimentar de vacas Holandesas em sistema de pastagens ou confinados. Instrução técnica para o produtor de leite. Minas Gerais: EMBRAPA (pp. 1-2).

Sbrissia, A. F., \& Da SILVA, S. C. (2001). O ecossistema de pastagens e a produção animal. In: Reunião Anual da Sociedade Brasileira de Zootecnia, 38., 2001, Piracicaba. Anais... Piracicaba: Sociedade Brasileira de Zootecnia (p.731-754).

Swenson, M. J. (1996). Dukes fisiologia dos animais domésticos (11th ed.). Guanabara Koogan. Rio de Janeiro.

Van Rees, H., \& Hutson, G. D. (1983). The behaviour of free-ranging cattle on an alpine range in Australia. Journal of Range management, 36(6), 740-743. http://dx.doi.org/10.2307/3898199

Van Soest, P. J. (1994). Nutritional ecology of the ruminant (2 ed.). Ithaca: Cornell University Press.

Vieira, B. R., Zanine, A. M., Ferreira, D. J., Ferreira, D. J., \& Vieira, A. J. M. (2007). Comportamento ingestivo de novilhas Girolando pastejando Brachiaria brizantha e Coast-cross no extremo-sul da Bahia. Magistra Cruz das Almas - BA, 19(1), 60-68.

Waring, E. S. E. (1975). The behaviour of horses. In E. S. E. Hafez (Ed.), The behaviour of domestic animals (3 ed.). Cordon: Bailliere Tindall.

\section{Copyrights}

Copyright for this article is retained by the author(s), with first publication rights granted to the journal.

This is an open-access article distributed under the terms and conditions of the Creative Commons Attribution license (http://creativecommons.org/licenses/by/3.0/). 